\title{
Corals and coral reefs of the Puerto Angel region, west coast of México
}

\author{
Héctor Reyes-Bonilla ${ }^{1}$ and Gerardo E. Leyte-Morales ${ }^{2}$ \\ 1 Departamento de Biología Marina. Universidad Autónoma de Baja California Sur. Apartado postal 19-B, CP 23080. La Paz, \\ B.C.S., México. \\ 2 Instituto de Recursos. Universidad del Mar. Apartado postal 47, CP 70902. Puerto Angel, Oax. México.
}

Received 5-VI-1997. Corrected 2-IV-1998. Acepted 15-IV-1998.

\begin{abstract}
Resumen: Se presentan datos sobre la riqueza de especies y las características de tres arrecifes de coral de la región de Puerto Angel, México $\left(15^{\circ} \mathrm{N}\right)$, visitados en 1994 y revisados en seis censos visuales de una hora, conducidos hasta $6 \mathrm{~m}$ de profundidad. Se encontró un total de siete especies en el área (pertenecientes a cuatro géneros), siendo la más abundante Pocillopora damicornis (L., 1758). Las especies de este género fueron las principales constructoras de la estructura arrecifal en los sitios visitados. Los corales masivos fueron poco comunes, y habitaban principalmente en la base de los arrecifes. Por la presencia de una estructura arrecifal bien cementada y una zonación clara, los arrecifes de franja de Puerto Angel deben ser considerados entre los mejor desarrollados de la costa del Pacífico de México. Un evento de mortalidad coralina y posterior recolonización fue observado en esta visita. Sin embargo, no se determinó cuál fue su causa.
\end{abstract}

Keywords: Puerto Angel, México, corals, eastern Pacific.

The coral communities and reefs of the eastern tropical Pacific have been studied for more than a hundred years (Guzmán \& Cortés 1993). However, data are still lacking from several long coastal margins, especially in México, where coral communities and reefs are well known only in the Gulf of California (Squires 1959, Reyes- Bonilla 1993).

The objective of this paper is to describe the general composition and structure of three coral reefs located near Puerto Angel, México: Playa Panteones, Playa Ixtacahuite and La Guacha (Fig. 1).

Palmer (1928) reviewed the geologic history of this area, described three species, and point out some general characteristics of local reefs. Later, the presence of two other coral species was confirmed (Geister 1975, RodríguezPalacios et al: 1988) and recently, Glynn \& Leyte- Morales (1997) and Leyte- Morales (1997) mentioned all reef areas located north of the Gulf of Tehuantepec, presented an updated species list, and emphasized the need for conservation of this biological systems.

The coral communities of Puerto Angel area occupied a small plateau that gradually reached 15 to $20 \mathrm{~m}$ depth at a distance of 50 to 100 from shore. The site is located near the Isthmus of Tehuantepec and local upwellings may occasionally affect the coral communities (LluchCota et al. 1997). Average sea surface temperature outside of Puerto Angel bay is $28{ }^{\circ} \mathrm{C} \pm 1.8$ (Anonymous 1982-1995). Salinity fluctuates from 33.5 to $34.5 \mathrm{ppm}$, and thermocline depth is 
stable at $60 \mathrm{~m}$ almost all year round in the area where coral development occurs (Fiedler 1992).

For this study, a total of six one- hour visual surveys were conduced at the three localities during January 1994, with snorkel and SCUBA equipment and at depths from 0 to $6 \mathrm{~m}$. Specimens of all the coral species observed were collected and deposited at the Instituto de Recursos, U. del Mar. Taxonomic determinations followed Wells (1983) and Veron (1986) criteria.

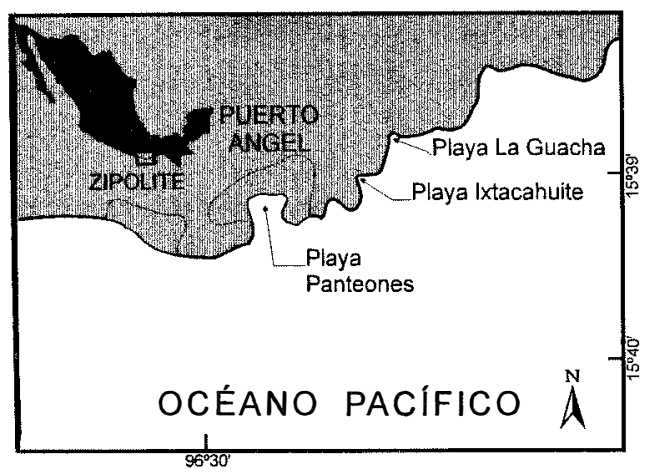

Fig. 1. Study area.

Seven species were found in the area: Pocillopora damicornis (L., 1758), P. capitata Verrill, 1864, P. meandrina (Dana, 1846), P. verrucosa (Ellis \& Solander, 1786), Pocillopora sp., Pavona gigantea Verrill, 1869 and Porites panamensis Verrill, 1866. Of these, Pocillopora damicornis was consistently the most abundant species in all the localities, followed by $P$. capitata; both were distributed mainly from 1 to $10 \mathrm{~m}$ depth, decreasing their abundance with depth. Other pocilloporid species were uncommon. Colonies of Porites panamensis were extremely scarce, encrusting, and appeared only at depths $<$ $3 \mathrm{~m}$. The agaricid Pavona gigantea was rare at all reefs, but it developed large colonies ( $>1 \mathrm{~m}$ height), especially on rocky zones and at depths from 3 to $5 \mathrm{~m}$.

The presence of an undescribed species (Pocillopora sp.) was one of the most remark- able findings. Its most distinctive character is that, unlike all other pocilloporids of the east Pacific, this one had no branches, but instead developed colonies with completely flat upper surfaces. The coralla are composed by pavements of polyps arranged in several levels, each one of these physically separated from the next. All levels are built by consecutive series of polyps (Leyte- Morales in prep.).

At La Guacha and Ixtacahuite, the reef framework projected 1 to $3 \mathrm{~m}$ from the bottom, it was well consolidated and composed predominantly of cemented pocilloporid corals. Large portions of its uppermost section and sides were dead and covered with coralline and fleshy algae and barnacles, but also had numerous small pocilloporid colonies (15 to $20 \mathrm{~cm}$ maximum diameter, 3 to $5 \mathrm{~cm}$ height) scattered over. Those coralla were classified as recruits, since a discontinuity among the framework and the base of the new coral existed (they were not fragments). Also, colonies were almost symmetrical and stemmed from one point, an indication of larval origin (Richmond 1987). Massive corals were almost absent in the main framework area, but they became increasingly common in the base of the reef ( $>5 \mathrm{~m}$ depth).

Before the visit, we supposed that the reefs of the Puerto Angel area may have a large number of species because of their closeness to the main eastern Pacific reefs at Central America, and of a possible larval transport from the north. The actual number of recorded species (seven) is, however, very low. During field work we did not find several taxa which have been already seen in nearby sites, like Gardineroseris planulata (Dana, 1846) or Pavona varians Verrill, 1864 (Leyte- Morales 1997). The presence of sandy bottoms at north and south of Puerto Angel and the upwellings in the Gulf of Tehuantepec may be acting as isolating forces, limiting larval arrival, and restricting the number of coral species (Glynn \& Leyte- Morales 1997).

The good development and zonation of the Puerto Angel reefs should result of the adequate local thermal conditions (mean monthly temperature is never lower than $27 \circ \mathrm{C}$ in the year; 
Fiedler 1992). These well- structured communities are potentially as old as others that show similar conditions elsewhere (Guzmán \& Cortés 1993). In comparison, zonation and large frameworks are uncommon at the apparently younger coral areas of the Gulf of California and the Revillagigedos (Squires 1959, ReyesBonilla 1993).

There are no reports of effects that El Niño events may have had on reef corals of Puerto Angel, although small thermal anomalies occurred in 1983 (<1.50 C; Lluch-Cota et al. 1997). Notwithstanding, large tracts of dead coral covered by algae were seen in 1994, all of them invaded and eroded by sea urchins (Diadema Gray, 1825, Echinometra Gray, 1825, Eucidaris Mortensen, 1909, Centrostephanus Peters, 1855 and Toxopneustes Agassiz, 1841), as it occurred at several bleached sites after 1982-83 (Guzmán \& Cortés 1993). If the coral mortality of Puerto Angel was not a consequence of an ENSO, it may have been a humancaused event; human population has increased considerably in the coast in the last decade because of the creation of a large governmentowned touristic infrastructure, which may have affected the coral communities in some way. However, we have no data to point to any factor as the actual cause of the dead coral tracts. New studies on this coral reefs will help to answer our questions and to evaluate its importance.

The visit of H.R.B. to Puerto Angel was supported by Juan Gabriel Díaz U. and Silvia Ramírez L. (UMar). Jose Carriquiry (IIOUABC, Ensenada) reviewed the manuscript and commented on several aspects here discussed. Two anonymous reviewers also suggested important additions for the paper.

\section{REFERENCES}

Anonymous. 1983-1995. Oceanographic monthly magazine. National Oceanographic and Atmospheric Agency. U.S. Dept. of Commerce, Washington, D.C.

Fiedler, P.C. 1992. Seasonal climatologies and variability of eastern tropical Pacific surface waters. NOAA Techn. Rep. NMFS 109. 65 p.
Geister, J. 1975. Occurrence of Pocillopora in late Pleistocene Caribbean coral reefs. Mem. Bur. Rech. Geol. Min. 89: 378-388.

Glynn, P.W. \& G.E. Leyte- Morales. 1997. Coral reefs of Huatulco, west México: reef development in upwelling Gulf of Tehuantepec. Rev. Biol. Trop. 45: 1033-1048.

Guzmán, H.M. \& J. Cortés. 1993. Arrecifes coralinos del Pacífico oriental tropical: revisión y perspectivas. Rev. Biol. Trop. 41: 535-557.

Leyte- Morales, G.E. 1997. La colección de corales de la Universidad del Mar. Cienc. Mar 1: 3-16.

Lluch- Cota, S.E., S. Alvarez- Borrego, E.M. Santamaríadel Angel, F. Muller- Karger \& S. Hernández-Vázquez. 1997. El Golfo de Tehuantepec y áreas adyacentes: variación espaciotemporal de pigmentos fotosintéticos derivados de satélite. Cienc. Mar. 23: 329-340.

Palmer, R.H. 1928. Fossil and Recent corals and coral reefs of western Mexico. Proc. Am. Philos. Soc. Philad. 67: 21-37.

Reyes- Bonilla, H. 1993. Biogeografía y ecología de los corales hermatípicos (Anthozoa: Scleractinia) del Pacífico de México, p. 207-222. In S.I. Salazar- Vallejo \& N.E. González (eds.). Biodiversidad marina y costera de México. Com. Nac. Biodiversidad/ C.I.Q.R.O, Chetumal, Q.R., México.

Richmond, R.R. 1987. Energetic relationships and biogeographical differences among fecundity, growth and reproduction in the reef coral Pocillopora damicornis. Bull. Mar. Sci. 41: 594-604.

Rodríguez- Palacios, C.A., L.M. Mitchell- Arana, G. Sandoval- Díaz, P. Gómez y G. Green. 1988. Los moluscos de las bahías de Huatulco y Puerto Angel, Oaxaca. Distribución, diversidad y abundancia. Univ. Cienc. 5: 85-94.

Squires, D.J. 1959. Corals and coral reefs of the Gulf of California. Bull. Am. Mus. Nat. Hist. 118: 367-432.

Veron, J.E.N. 1986. Corals of Australia and the Indo Pacific. Angus and Robertson, Sydney. 544 p.

Wells, J.W. 1983. Annotated list of the scleractinian corals of the Galapagos Islands, p. 212-295. In Glynn, P.W. \& G.M. Wellington (eds.). Corals and coral reefs of the Galapagos Islands. University of California, Berkeley. $330 \mathrm{p}$. 